\title{
A Review: Aquatic Macrophyte Ceratophyllumdemersum L. (Ceratophyllaceae): Plant Profile, Phytochemistry and Medicinal Properties
}

\author{
Thomas Abu \\ Genetic Engineering Bioresources Laboratory Unit, Bioresources Development Centre, Odi, Nigeria
}

\begin{abstract}
Ceratophyllumdemersum(CD) (Ceratophyllaceae) is one of the important and fascinating aquatic macrophyte that has a little recognition in traditional system of medicine for the treatment of various life threatening diseases and other areas in which its use can be utilized. There is less knowledge available about phytoconstituents and medicinal properties of the plant. In other words, compiled information about its phytoconstituents, medicinal properties and other related information is lacking till date. In the present review, the author tried to compile all the phytoconstituents, medicinal and other related information of CD and fill the knowledge lacuna in this particular field and encourages further study on the plant and other aquatic macrophytes as these definitely will help in developing potential biopharmaceutical product.
\end{abstract}

Keywords: Ceratophyllumdemersum, aquatic macrophyte, phytoconstituents, medicinal properties

\section{Introduction}

Aquatic macrophytes are water vegetation comprising macroalgae and the true angiosperms. They form the bases of aquatic ecosystemsand play fundamental roles in nutrient cycling of water bodies and provide suitable habitats for many other animals. They also determine the physicochemical properties and nutrient cycling of water bodies. Aquatic macrophytes may be classified as emergent (e.g. cattails), free-floating (e.g. water lilies), or submerged macrophytes (e.g. coontail) [1, 2, 3].

\section{Plant Profile}

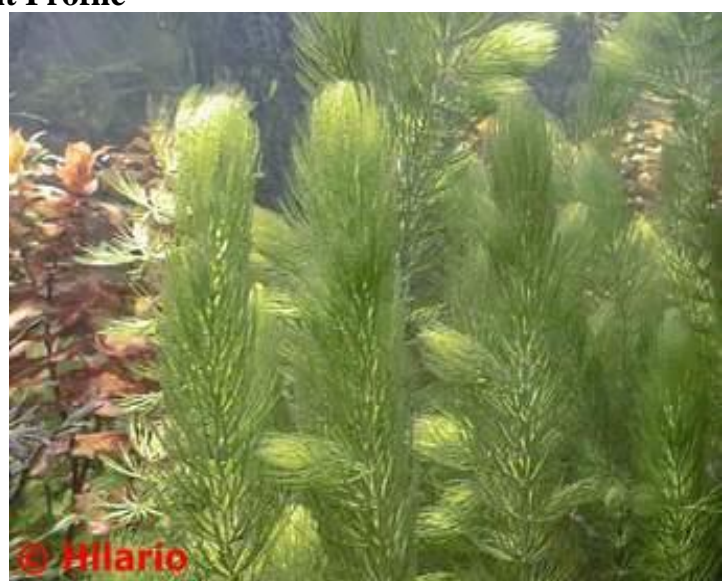

Source: www.hilario_free_fr.com

Domain: Eukaryota

Kingdom: Plantae

Division: Spermatophyta

Sub-division: Angiospermae

Class: Dicotyledonae

Order: Nymphaeales

Family: Ceratophyllum

Species: demersum
Ceratophyllumdemersum (CD) also known as coontail or hornwort is a dicotyledonous, submerged aquatic angiosperm belonging to the family Ceratophyllaceae. This family comprises three species: $C$. demersum, $C$. submersum and $C$. muricatum. C. demersum occasionally branches but with a single branch produced per node. Leaves are middark green, rigid sessile, in whorls of 6-8, dichotomously divided (1- or 2-3-forked) into linear segments with 4 or 5 prominent teeth marginally. Roots are lacking, but leafy branches are sometimes modified as rhizoids; stems break easily and the pieces continue growth separately. Flowers are unisexual; both staminate and pistillate on the same plant; very small, solitary in axil of one leaf of a given whorl, each subtended by an 8-12-part involucres; they have no perianth. The staminate flowers have 4-10 stamens, with very short filaments, anthers with a connective projecting distally and ending in 2 bristles. Pistillate flowers have 1 pistil and a superior, 1-locular, ovary. The fruit is 1-seeded, ovoid-oblong $4-6 \mathrm{~mm}$ long achene, with spineless, lateral margins and 1 or 2 basal spines [4].It exhibits a cosmopolitan distribution and has a wide ecological tolerance [5]. CD occurs in quiet or slow flowing, hard calcareous nutrient-rich or eutrophic waters of streams, ditches, canals, ponds and lakes as a near free-floating aquatic plant where it may form large masses [6,7]. It perennate in temperate regions by dormant apices on the lake bottom where these organs are covered by a layer of detritus. Dormancy is initiated in late summer and autumn when elongation growth of the lateral shoots ceases, and tightly clustered, dark-green leaves, which contain high levels of starch, are formed [8].

$\begin{array}{llrr}\text { The natural enemies } & \text { of } & \text { C. demersum } & \text { are } \\ \text { Ctenopharyngodonidella } & \text { (a predator) } & {[9,10],} \\ \text { Hirschmanniellacaudacrena } & \text { (parasite) } & \text { [11] } & \text { and }\end{array}$
Mycoleptodiscusterrestris (pathogen) [12] 


\section{International Journal of Science and Research (IJSR) \\ ISSN (Online): 2319-7064}

Index Copernicus Value (2015): 78.96 | Impact Factor (2015): 6.391

C. demersum has been widely used as bioindicators of heavy metals in air pollution, radioactivity indicators [13,14],biomonitoring [15] in the aquatic environment, genetic engineering [16]. It is also one of the popular plants in aquatic industrydue to its tolerance in a wide range of aquatic conditions [17,18]. It also provides an excellent living environment for shelter to fish and aquatic organisms. It is also used as a source of food for some livestock, poultry [19] and fish [20].C. demersum is astringent, bitter, sweet, oleaginous, fragrant and purgative [21]

\section{Material ad Methods}

In the present review, information about Ceratophyllumdemersum and its phytochemical constituents, medicinal properties and biochemical properties was gathered via searching scientific databases including PubMed, Elsevier, Google Scholar, Springer etc. and other related books either online or offline.

\begin{abstract}
Aim of Present Review
Information about medicinal properties of $C$. demersumL. and its phytoconstituents is segregated and not presented in well documented form. In the present review, information has been compiled regarding tophytochemistry, medicinal properties and other related information of CeratophyllumdemersumL.
\end{abstract}

\section{PHYTOCHEMISTRY}

C. demersum plant extracts consist of different classes of phytomolecules such as alkaloids, cardiac glycoside, glycosides, tannins and flavonoids [22,23]. The proximate composition (\% of dry weight) of $C$. demersum includes dry matter $(6.9 \%)$, crude protein (15.8), ash (25.3), crude Fat (3.0), crude fibre (20.7), nitrogen free extract (35.2), calcium and magnesium [24, 25,26].The essential oil from leaves of C.demersumwas isolated by steam distillation in yield of $0.15 \%$ and its chemical composition was examined by GC and GC-MS. The main components present in the plant's essential oil include 2-Methylpropanoic acid 3-hydroxy2,4,4-trimethylpentyl ester (>15\%), 2-methylpropanoic acid 2,2-dimethyl-1-(2-hydroxy-1-methylethyl)propyl ester $(>3 \%), \beta$-ionone-5,6-epoxide $(>7 \%)$, toluene $(>6 \%)$, hexanal $(>5 \%)$ and 1,2-benzenedicarboxylic acid di(2-methylpropyl) ester $(>5 \%)$ [27]. Tricin-7-O- $\beta$-D-glucoside, naringenin-7O- $\beta$-D-glucoside, esculetin, $\beta$-sitosterol, $7 \alpha$-hydroxyl- $\beta$ sitosterol, $7 \alpha$-methoxyl- $\beta$-sitosterol and palmiticacid were also isolated from $C$. demersum [28]. In another study, two flavonoid glycosides were also isolated and one was identified as apigenin-7-O-glucoside. Seven sterols, the main one sitosterol, were also identified. Volatile compounds contained mainly n-paraffins, together with benzyl acetate and a sesquiterpene were isolated and identified [29].Gentisic acid, vitamin C,coumaric acid, ferulic acid and beta-carotene were also detected in the extract of $C$. demersum in another study [30].

\section{Medicinal Properties}

\section{Ethnomedicinal Properties}

The ethnomedicinal uses of the plant $C$. demersum suggested vital role in the treatment of various diseases. Its juice mixed with sesamum oil is prescribed for discoloured skin.10-15ml decoction of the plant given twice daily for 7 10 days cures biliousness and ulceration[31,32]. InIndian medicine, the herb is used in jaundice, for scorpion stings, as an antipyretic and antimalarial. In china, it is used with hemoptysis. The plant is a cooling antiperiodic and also useful in the treatment of diarrhea, dysentery and constipation. It is carminative, styptic.The whole plant has been traditionally used in the treatment of wounds, fever, burning sensation, haemorrhoids or piles, intrinsic haemorrhages, hyperdipsia, epistaxis, haematemasis [21, 33]. It is prescribed for cardiac infections, giddiness, haemothermia, leucorrhoea, morbid thirst, rheumatism spermaturia, venereal diseases [32,34]. Leaf juice is used to stop vomiting, as cooling agent and to cure skin disorders[35, 36].

\section{Pharmacological Properties}

A long history of $C$. demersum has led modern day researcher to study the various extracts and its significant pharmacological activities. Its traditional use against dysentery, pyretic and wounds has been validated in various studies.

\section{Antidiarrhoeal and wound healing activity}

The methanol and aqueous extracts of whole plant of Ceratophyllumdemersumwere assessed for antidiarrhoeal and wound healing potentials using experimental models in rats. Acute oral toxicitystudies were performed according to the OECD 423 guidelines. All the doses of $(5,50,300,2000$ and $5000 \mathrm{mg} / \mathrm{kg}$ ) of methanol and aqueous extracts employed for acute oral toxicity studies were found to be non-toxic. Both the extracts did not produce any mortality even at the highest dose $(5000 \mathrm{mg} / \mathrm{kg})$. Antidiarrhoeal activity at a dose of $250 \mathrm{and} 500 \mathrm{mg} / \mathrm{kg}$ was evaluated in castor oil and magnesium sulphate induced diarrhoea in rats and the parametersstudied were: total no. of faeces, no. of wet faeces, percentage inhibition of defecation and diarrhoeicdrops. Wound healing activity of the both the extracts $(5 \% \mathrm{w} / \mathrm{w}$ ointment in simple ointment base)was evaluated in excision wound model and the parameters taken into account were percentage of woundclosure and epithelialization time. Both the extracts at a dose of 500 $\mathrm{mg} / \mathrm{kg}$ showed significant antidiarrhoealand also showed significant wound healing activities (5\% w/w) [22].

\section{Antioxidant and anti-acetylcholinesterase (AChE) activity}

The ethanol extracts from CeratophyllumdemersumL. was assessed with other aquatic plantsin vitro for their antioxidant and anti-acetylcholinesterase (AChE) activities. Antioxidant activity was evaluated by 2,2-diphenyl-1picrylhydrazyl (DPPH) radical scavenging activity test at $0.125,0.25,0.5,1.0$, and $2.0 \mathrm{mg} / \mathrm{ml}$ and ferric-reducing antioxidant power assay (FRAP) at $0.5,1.0$, and $2.0 \mathrm{mg} / \mathrm{ml}$ concentrations. Total phenolic contents (TPC) of the extracts were determined using Folin-Ciocalteau's reagent. The TPC of the extract was 528.29 \pm 4.07 and percentage of inhibition against DPPH radical include; at $0.5,1.0$ and $2.0 \mathrm{mg} / \mathrm{ml}$ concentration, the values were $12.2 \pm 1.06,22.6 \pm 0.62$ and $39.3 \pm 1.11$ as against the reference using Gallic acid (GA) and BHA at the same concentration with values of GA $(91.6 \pm 0.06,92.6 \pm 0.10$ and $93.2 \pm 00)$ and BHA $(77.9 \pm 0.48$, $81.6 \pm 1.67$ and $82.9 \pm 0.66)$. In FRAP, at 0.5 and $1.0 \mathrm{mg} / \mathrm{ml}$, 


\section{International Journal of Science and Research (IJSR) \\ ISSN (Online): 2319-7064}

Index Copernicus Value (2015): 78.96 | Impact Factor (2015): 6.391

the values were $0.329 \pm 0.02$ and $0.609 \pm 0.02$ against GA and BHA at 0.25 and $0.50 \mathrm{mg} / \mathrm{ml}$ with values of $\mathrm{GA}(3.569 \pm 0.02$

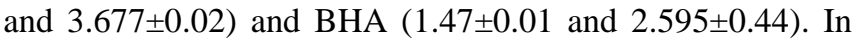
the anti-AChE assay, the extract exerted insignificant inhibition against the enzyme at $1.0 \mathrm{mg} / \mathrm{ml}$ and $2.0 \mathrm{mg} / \mathrm{ml}$ concentrations which had percentage inhibition of $7.1 \pm 1.92$ and 11.2 \pm 2.81 with reference drug (Galanthamine) which had 98.9 \pm 0.24 [29].

Invitro free radical scavenging activities of aqueous and methanol extracts from invitro propagated $C$. demersum using DPPH were investigated. The extracts from $C$. demersum were effective in the following order: water>methanol. DPPH scavenging activities of treatments with maximum concentration $(10 \mathrm{mg} / \mathrm{ml})$ of water and methanol extracts were 68.91 and $51.22 \%$ respectively and $\mathrm{IC}_{50}$ values of water and methanol extracts showed aqueous as most effective extract with $3.689 \mathrm{mg} / \mathrm{ml}$ and methanol extract having $10.301 \mathrm{mg} / \mathrm{kg}$. gallic acid (standard drug) was computed as $0.029 \mathrm{mg} / \mathrm{ml}$ with statistically $(\mathrm{p}<0.05)$ significant difference between this value and the values belonged to extracts [37].

In another study, the response of $C$. demersumwhen exposed to 1,2- and 1,4-dichlorobenzene (1,2-DCB and 1,4-DCB) through the assay of glutathione reductase (GR), guaiacol peroxidase (POD) and glutathione peroxidase (GPx) was evaluated. Additionally, the effect of DCBs on the detoxication system by measuring the activity of glutathione- $S$-transferase (GST) was also evaluated.The plantshowed elevated GST activities when exposed to 10 and $20 \mathrm{mg} / 1 \mathrm{1}, 2-\mathrm{DCB}$, and at $10 \mathrm{mg} / \mathrm{l}$ for $1,4-\mathrm{DCB}$. The results showed that glutathione conjugation take place at relatively high concentrations of both isomers. Significantly increased activities of POD were also detected in $C$. demersum exposed to concentrations above $5 \mathrm{mg} / \mathrm{l}$ of the corresponding isomer. The GR activity was enhanced in plants exposed to 1,2-DCB (5 mg/l) and 1,4-DCB $(10 \mathrm{mg} / \mathrm{l})$. GPx was also significantly increased in exposures to the corresponding isomer, each at a concentration of $10 \mathrm{mg} / \mathrm{l}$. However, plants exposed to low doses of 1,4-DCB $(1 \mathrm{mg} / \mathrm{l})$ showed significantly decreased activities of both enzymes GR and GPx. Consequently, this study showed that the exposure of the aquatic macrophyte $C$. demersum to DCBs was able to cause an activation of the antioxidant system, showing an isomer specific pattern, which suggests that the defence system of the plant is playing an important role in scavenging ROS, helping to protect the organism against adverse oxidative effects generated by the prooxidant action of the tested xenobiotics [38].

\section{Antimicrobial activity}

The antimicrobial activity of Ceratophyllumdemersumwith othermacrophyteswere extracted with three different solvents like acetone, butanol and methanol and determined theactivity against two pathogenic organisms both Gram positive (Staphylococcus aureus) and Gram negative (Escherichia coli) bacteria and fungi (Aspergillusniger) by agar well diffusion method.Antifungal property was found in $50 \%$ acetone extract causing inhibition zone $18 \mathrm{~mm}$ of C.demersum against Aspergillusniger. There was no activity recorded for the plant extract against Staphylococcus aureusand Escherichia coli [23]. In another study, the antimicrobial activities of aqueous and organic solvents (chloroform, ethanol and methanol) extracts of Ceratophyllumdemersum L., with other plants were tested in vitro against seventeen different microorganisms including Gram-positive and Gram-negative bacteria and fungi. Nine of these identified organisms were obtained from different sources, Bacillus subtilis 1020, Bacillus cereus 1080, Staphylococcus aureus, Erwiniacarotovora NCPPB 312, Candida albicans, Candida tropicalis, Aspergillusniger, Fusariumoxysporum and Penicilliumitalicum. The other eight organisms were isolated from another source and identified using API 20E strip system (BioMereux). One hundred pathogenic bacteria isolates representing eight genera were identified to species level. These organisms are Escherichia coli (20\%), Pseudomonas aeruginosa (16\%), Klebsiellapneumoniae (14\%), Salmonella colerasuis (13\%), Shigella sp. (11\%), Serratialiquefaciens (10\%), Proteus vulgaris $(9 \%)$ and Brennerianigrifluens (7\%). The extract demonstrated antimicrobial activity against the used organisms. The efficiency of the extracts varied with, solvent used in the extraction. The aqueous extract appeared to be the highly effective extract against all tested organisms especially Fusariumoxysporum causing inhibition zone $48 \pm$ $0.01 \mathrm{~mm}$, Pseudomonas aeruginosa $59 \pm 0.02 \mathrm{~mm}$ and Salmonella cholerasuis $55 \pm 0.01 \mathrm{~mm}$ when using $C$. demersum. Ethanol extract of $C$. demersumshowed antimicrobial activities against all tested organisms except Aspergillusniger. On using chloroform extracts Escherichia coli, Aspergillusniger and Penicilliumitalicumshowed resistance [26].

\section{Antineoplastic and anti-inflammatory activity}

The assessment of the spectrum of biological activities (antineoplastic and anti-inflammatory) with prediction of activity spectra for substances (PASS) for the major components of essential oil of $C$. demersum along with other plants extracted with hexane was studied. The predicted value of anti-inflammatory and antineoplastic activities with probability above 0.8 was observed for 12 compounds (2Z,4Z)-Hepta-2,4-dienal; 2-Phenylacetaldehyde; (3E,5E)Octa-3,5-dien-2-one; 2,6-Dimethylcyclohexan-1-ol; geranylacetone; $\alpha$-muurolene; $\quad \beta$-ionone; $\beta$-eudesmol; $\alpha$ eudesmol; biformen; kaurene and manool[39].

TheAnti-inflammatory activity of methanol extract of whole plant of $C$. demersum was also testedusing the carrageenan induced rat paw edema model at the doses of 250 and 500 $\mathrm{mg} / \mathrm{kg}$ with $1 \% \mathrm{CMC}(10 \mathrm{mg} / \mathrm{kg}$ p.o $)$ as control and Nimesulide $(50 \mathrm{mg} / \mathrm{kg}$ p.o). The methanol extract of $C$. demersum at the dose of 250 and $500 \mathrm{mg} / \mathrm{kg}$ body weight showed significantly $(\mathrm{p}<0.01)$ reduction paw volume[39].

\section{Analgesic and antipyretic activity}

Acetic acid induced writhing model was employed to evaluate the analgesic activity. Albino mice $2025 \mathrm{gm}$ body weights were divided into four groups of six animals each. First group of the animals received $1 \%$ CMC(10ml/kgofb.w., p.o.) served as control, second group served as reference standard received Nimesulide (50mg/kgofb.w.,p.o) while third and fourth group received methanolextract (250 and $500 \mathrm{mg} / \mathrm{kgofb} . w ., \quad$ p.o. $)$, respectively. The vehicle, extractand standard drug administered orally $1 \mathrm{~h}$. prior to the intraperitoneal

\section{Volume 6 Issue 7, July 2017 www.ijsr.net}




\section{International Journal of Science and Research (IJSR) \\ ISSN (Online): 2319-7064}

Index Copernicus Value (2015): 78.96 | Impact Factor (2015): 6.391

administration of acetic acid injection $(10 \mathrm{ml} / \mathrm{kg}$ of $0.6 \%$ $\mathrm{v} / \mathrm{v})$. The writhing effect indicated by the contraction of abdomen with simultaneous extension of hind limbs and trunk twist response. The analgesic activity was expressed in term of percentage inhibition of writhesproduced by acetic acidwas calculated by using the formula, Percentage inhibition of writhes=Mean of Control -Mean of Test $\times 100 /$ Mean of Control.

The antipyretic activity was evaluated using Brewer's yeast(Saccharomyces cerevisiae)induced pyrexia method in Wistar rats.Before the experiment, the rats were maintained in separate cages with food and water ad libitum for 7 days and the animals with approximately constant rectal temperature $(37.5-38.40)$ were selected for the study. Male Wistar albino rats weighing, 150-200 gm were divided into four groups of six animals each. First group of the animals received $1 \% \mathrm{CMC}(10 \mathrm{ml} / \mathrm{kg}$ of b.w., p.o.) served as control, second group served as reference standard received Paracetamol (50 mg/kg of b.w.,p.o) while third and fourth group received methanol extract (250 and 500 of $\mathrm{mg} / \mathrm{kg}$ b.w., p.o.), respectively. Fever was induced by injecting 2 $\mathrm{ml} / \mathrm{kg}$ of $20 \%$ aqueous suspension of Brewer's yeast in distilled water and $18 \mathrm{~h}$ after yeast injection the vehicle, extract and standard drug were administered. Rectal temperature was recorded by clinical thermometer at $0,1,2$, $3 \mathrm{~h}$ after drug administration. The methanol extract of C.demersum(MECD) at thedose of 250 and500 $\mathrm{mg} / \mathrm{kg}$ body weight showed significantly ( $\mathrm{p}<0.01$ )reduction innumber of writhes and paw volumeand at the dose $500 \mathrm{mg} / \mathrm{kg}$ body weight showed significantly $(\mathrm{p}<0.05)$ reduction in pyrexia [40].

\section{Allelopathic and genotoxic activity}

The genotoxic potential of aqueous extract of $C$. demersumwas evaluated along with other aquatic plants using the micronucleus test and to find possible correlation with the total polyphenol and tannin content. For genotoxicity assessment, the mussel micronucleus test was applied. Micronucleus frequency was determined from the haemolymph of UniopictorumL. (painter's mussel). In parallel, total and hydrolisable tannin contents were determined. The plant extract elucidated significant mutagenic effect. Significant correlation was determined between tannin content and mutagenic capacity. The significant correlation between genotoxicity as expressed by micronucleus frequency and tannin content (both total and hydrolisable tannins) indicate that tannin is amongst the main compounds being responsible for the genotoxic potential which might suggest the genotoxic capacity of the plant to elucidate a real ecological effect in the ecosystem [41].

The allelopathic activity of Ceratophyllumdemersum was also evaluated anda bioassay-directed method development revealed optimal extraction solvents for allelochemicals from the plant. Extracts of Ceratophyllumdemersuminhibited both Anabaena PCC 7120 and Synechococcuselongatusat all tested concentrations and with all solvent mixtures used. Ceratophyllum 50\% acetone yielded the strongest inhibition in the agar-diffusion assay with various filamentous or chroococcal cyanobacteria as target species. Further fractionation by liquid-liquid extraction (LLE) and solid phase extraction (SPE) procedures showed that the aquaticmacrophyte appear to have more than one active fraction, one being hydrophilic and one moderately lipophilic. The water-soluble allelochemicals may inhibit phytoplankton whereas the lipophilic allelochemicals may act through direct cell-cell contact, e.g., against epiphytes. The macrophyte also exuded allelopathically active compounds into the surrounding medium as shown by SPE of their incubation water [42].

In another study, the potential relationships between the phytochemical compounds detected in the plant extract (acids, phenols, heterocycles, alcohols, hydrocarbures) and the allelopathic properties against Gram positive and Gram negative bacterial strains and microalgal cultures were investigated. The untargeted solid phase micro extraction (SPME) GC/MS analysis performed on the dried plants incubated for $25 \mathrm{~min}$ at $50^{\circ} \mathrm{C}$ showed that phenols are the major constituents of the volatile fingerprint with a relative peak area higher than 13\%, namely: 2,6 bis $(1,1-$ dimethylethyl)-4(1-oxopropyl) phenol and phenol, 3,5-bis (1,1-dimethylethyl). The inhibition effects ex situ of the analyzed extracts suggested that the aquatic macrophyte may excrete inhibitory substances and show allelopathic inhibitory potential against certain bacterial strains and on Rhizocloniumhieroglyphicum and Microcystisaeruginosa cultures [43].

\section{Conclusion}

Natural products have been an important resource for the maintenance of life since ages and are becoming increasing important as alternative medicine. $C$. demersum had a long history of traditional uses for wide range of diseases. $C$. demersum plant studied in this review article is important as alternate for various disease research and treatment. This plant and their folkloric/traditional pharmacological profile need to be preserved. In recent years, it has been experimentally proved that this plant possess a number of biological activities. However, scientific validation of the plant as a modern medicine is lacking. Further studies need to be carried out to explore its potential and other aquatic macrophytes in the treatment of diseases by using isolated compounds with minimal or no side effects. More so, ensuring the safe use of theseplants should be strived more. This plant needs effective utilization in order to make a hallmark through complete diseases cure and cheap regimen to be available for ordinary population vis-à-vis helping indeveloping potential biopharmaceutical product.

\section{Disclosure/Conflict of Interest Statement}

The author of this paper has no financial or personal relationship with other people or organizations that could inappropriately influence or bias the content of the paper. It is to specifically state that "No Competing interests are at stake and there is No Conflict of Interest" with other people or organizations that could inappropriately influence or bias the content of the paper. The manuscript has not been published previously by any of the authors and/or is not under consideration for publication in another journal at the time of submission.

\section{Volume 6 Issue 7, July 2017 www.ijsr.net}




\section{International Journal of Science and Research (IJSR) \\ ISSN (Online): 2319-7064}

Index Copernicus Value (2015): 78.96 | Impact Factor (2015): 6.391

\section{References}

[1] OyedejiAA., AboweiJFN.The

Classification, Distribution, Control and Economic Importance of Aquatic Plants. International Journal of Fisheries and Aquatic Sciences.2012; 1(2): 118-128.

[2] PanditAK.,QuadriMY. Nutritive values of some aquatic life forms of Kashmir. Environ. Conserv.1986; 13:260262.

[3] Pompeo MLM., Moschini-Carlos V. Macrófitasaquaticas e perifiton, espectosecológicosemetodológicos. 2003;Sao Carlos: RiMa 134.

[4] Godfrey RK.,Wooten JW. Aquatic and wetland plants of the south-eastern United States: Dicotyledons. 1981;Athens, Georgia: Univ. Georgia press.

[5] Cook CDK. Origin, autecology and spread of some of the worlds' most troublesome aquatic weeds. In: Pieterse AH., Murphy KJ, eds. Aquatic weeds: the ecology and management of nuisance aquatic vegetation.1990; Oxford, UK: Oxford university press, 31-39.

[6] Best EPH. Effects of nitrogenous compounds of Ceratophyllumdemersum. Aquatic Botany. 1980;8(2):197-206.

[7] Kulshreshtha M. Comparative ecological studies on two species of Ceratophyllum.Proceedings $6^{\text {th }}$ EWRS International symposium on Aquatic weeds.1982;29-36.

[8] Pomogyi P., Best EPH.,DassenHHA.,BoonJJ. On the relation between age, plant composition and nutrient release from living and killed Ceratophyllum plants. Aquatic Botany.1984;19(3/4): 243-250.

[9] Santha CR.,Martyn RD.,Neill WH., Strawn K. Control of submersed weeds by grass carp in water lily production ponds. Journal of Aquatic plant management.1974;32:29-33.

[10] Khattab AF.,El-Gharably Z. Management of aquatic weeds in immigration systems with special reference to the problem in Egypt. Proceedings, $7^{\text {th }}$ international symposium on aquatic weeds. 1986; 199-206.

[11] Gerba K., SmartGCJr. Effect of Hirschmanniellacaudacrena on the submersed aquatic plants Ceratophyllumdemersum and Hydrillaverticillata. Journal Nematology.1987;19(4):447-453.

[12] Verma U., Charudattan R. Host range of Mycoleptodiscusterrestris, a microbial herbicide candidate for Eurasian watermilfoil, Myriophyllumspicatum. Biological control, 1993;83(4): 271-280.

[13]Fawzy MA., El-SayedBadr N., El-Khati A., El-kassem AA. Heavy metal biomonitoring and phytoremediation potentials of aquatic macrophytes in River Nile. Environmental monitoring and Assessment.2012;184(3), 1753-1771.

[14] Aravind P., Prasad MNV. "Cadmium-Zinc interaction in hydroponic system using Ceratophyllumdemersum L.: adaptive ecophysiology, biochemistry and molecular toxicology". Journal of plant physiology. 2004;17, 117125.

[15] Park S., Kang D., KimY., Lee AM., Chung Y., Sung K. Bisorption and growth inhibition of wetland plants in water contaminated with a mixture of arsenic and heavy metals. Engineering in Life sciences, 2011; 11, 84-93.

[16] Shabnam A., Saeed A. An efficient and simple CTAB based method for total genomic DNA isolation from low amounts of aquatic plants with a high level of secondary metabolites. Progress in Biological Sciences. 2016;6(1):95-106.

[17] Rahman AHMM.,Rafiul Islam AKM., Naderuzzaman ATM., Hossain MD., AfzaR.Studies on the aquatic angiosperms of the Rajshahi university campus. Research Journal of Agriculture and Biological sciences. 2007;3, 474-480.

[18] Anonymous, Ceratophyllumdemersum. 2013.(http://www.floridaaquatic.com/aquariumplant_Ceratophyllum_demersum.html).

[19] Anonymous, supplementary and complete feeds. 2013. (http://www.fao.org/docrep/field/003/T8389E03.htm).

[20]Laining A., Kristanto AH. 2005.Aquafeed development and utilization of alternative dietary ingredients in aquaculture feed formulations in Indonesia. In: proceeding of ASEAN-SEAFDEC Regional Technical Consultation on Development and use of alternative dietary ingredients for fish meal substitutes in aquaculture feed formulation. Catacutan MR., Coloso RM., Acosta BO. (eds), (2014), Nay Pyi Taw, Myanmar, South East Asian Fisheries Development Centre, Aquaculture Department, Tigbauan, Iloilo, Philippines.

[21]R. Vasudevan Nair. Indian medicinal plants: A compendium of 500 species. Orient Blackswan. 1997.

[22] Ashok DT., Atul MK., Karale SS.,Yashodhan BW.Evaluation of Antidiarrhoeal and Wound Healing Potentials of CeratophyllumdemersumLinn. Whole Plant in Rats. Lat. Am. J. Pharm. 2011; 30 (2): $297-$ 303.

[23] Malathy R., Shaleesha AS. Studies on the potential therapeutic effects on the aquatic macrophytes namely Cabombaaquatica, Ceratophyllumdemersum and Hygrophilacorymbosa.Journal of Chemical and Pharmaceutical Research.2015; 7(4):479-483.

[24] Anjana B., Matai S. Composition of Indian Aquatic Plants in relation to utilization as Animal forage. $J$. Aquat. Plant Manage.1990; 28: 69-73.

[25]Linn JG., StabaEJ., Goodrich RD., Meiske JC., Otterby DE. Nutritive value of dried or ensiled aquatic plants I. Chemical composition. Journal of Animal science. 1975; 41:601-609.

[26] FareedMF.,Haroon AM., Rabeh SA. Antimicrobial Activity of some Macrophytes from Lake Manzalah (Egypt).Pakistan Journal of Biological Sciences.2008; 11 (21): 2454-2463.

[27]Xian Q., Chen H., Zou H., Yin D. Chemical composition of essential oils of two submerged macrophytes, Ceratophyllumdemersum L. and VallisneriaspiralisL.FlavourFragr. J., 2006; 21: 524 526

[28] Xiao-Li L., Ying Q.,Xian-Min Z.,Bo-Lin M., Ming-Hua Q. Chemical constituents from Ceratophyllumdemersum (Ceratophyllaceae). Acta Bot. Yunnanica. 2003; 29, 263-264.

[29] Bankova V., Ivanova P., Christov R., Popov S., Dimitrova-Konaklieva St. Secondary metabolites of 


\section{International Journal of Science and Research (IJSR) \\ ISSN (Online): 2319-7064 \\ Index Copernicus Value (2015): 78.96 | Impact Factor (2015): 6.391}

Ceratophyllumdemersum. Hydrobiologia. 1995; 316(1)59-61.

[30] Kartal M., Orhan I.,Abu-Asaker M., ŞenolFS.,Atici T.,Şener B.Antioxidant and Anticholinesterase Assets and Liquid Chromatography-Mass Spectrometry Preface of Various Fresh-Water and Marine Macroalgae. Pharmacognosy Magazine [Phcog Mag].2209; 5(20): 291-297

[31] Pullaiah T. Encyclopaedia of World Medicinal Plants (Vol. 1). New Delhi: Dayabooks; 2006; 513e514.

[32] Vaidyaratnam PS. Indian medicinal plants: CeratophyllumdemersumLinn, Orient Longman Ltd., Madras. 1997; 2: 56.

[33] Yuan Z.,Xie Y. 2009. Illustrated Encyclopedia of Chinese herbal medicine. Peking: Zhongyigujichuban she.

[34] Kumar S., Narain S. Herbal remedies of wetlands macrophyte in India. International Journal of Pharma and Biosciences.2010; 1(2).

[35] Arvind S., Manavendra KS., Dharmendra KS., Ritesh S.Ethnomedicinal studies on wetland plant diversity of district Buxar (Bihar, India). Unique Journal of Pharmacy and Biological science. 2013; 01(02):18-20

[36] Sing OR., Das B., Padhi MM., Tewari NS. Common herbs used in different skin disordersasdescribed in ayurvedic classics. Ancient science of life. 2003; 22(3).

[37] Mehmet K.,Muhammet D.,Bugrahan E., Muhammad A. Determination of in vitro free radical scavenging activities of various extracts from in vitro propagated Ceratophyllumdemersum L. Fresenius Environmental Bulletin. 2015; 24, 9a.

[38] Monferran MV.,Wunderlin DA., Nimptsch J., Pflugmacher S. Biotransformation and Antioxidant response in Ceratophyllumdemersum experimentally exposed to 1,2- and 1,4- Dichlorobenzene. Chemosphere. 2007; 68(11):2073-2079.

[39] KurashovEA.,Fedorova EV., Krylova JV., Mitrukova GG. Assessment of the Potential Biological Activity of Low MolecularWeight Metabolites of FreshwaterMacrophytes with QSAR.Scientifica. 2016; (9).

[40] Karale SS.,Jadhav SA., Chougule NB., Awati SS., Patil AA. Evaluation of Analgesic, Antipyretic and AntiInflammatory Activities of CeratophyllumDemersumLinn. in Albino Rats. Current Pharma Research. 2013; 3 (4): 1027-1030

[41] Bettina E-V., KovátsN., Hubai K., Paulovits G., FerinczÁ., Horváth E. Screening potential genotoxic effect of aquatic plant extracts using the mussel micronucleus test.Journal of Coastal Life Medicine.2006; 4(1): 36-38

[42] Elisabeth MG., Daniela E.,Enikö I. Allelopathic activity of CeratophyllumdemersumL. and Najas marinassp.intermedia(Wolfgang) Casper.Hydrobiologia. 2003; 506, pp. 583-589.

[43] Mariana L.,Daniela B.,Elena B. Allelopathic potential of the Ranunculus rioniiLagger and Ceratophyllumdemersum Linn. extracts against microbial and microalgal cultures. Environmental engineering and management Journal. 2016; 15(2):473480.

Volume 6 Issue 7, July 2017 www.ijsr.net 